\title{
The informativeness of voluntary disclosure in the annual reports of listed industrial companies in South Africa
}

\author{
JE Myburgh \\ Department of Accounting and Finance \\ University of Pretoria
}

\begin{abstract}
Users of annual reports require an extensive range of financial and non-financial information, whether mandatory or voluntary, in order to assess the fair value of an investment. The extent and quality of voluntary information is dependent on company policy, and companies need to make decisions in favour of or against the disclosure of certain informative items. A survey was conducted to examine the perceptions of the compilers and the users of annual reports on the price-informative value of voluntary disclosures in annual and interim reports. The rankings awarded by compilers and users to the various voluntarily disclosed items were compared in order to determine the significance of the differences between the perception of the two groups. Significant differences were identified and suggestions are made for the improvement of corporations' voluntary disclosure strategies.
\end{abstract}

Key words

Financial reporting

Voluntary disclosure

Discretionary disclosure

Non-mandatory disclosure

\section{Introduction}

In order to satisfy the growing information needs of the users and the compilers of annual reports in the 21st century, emphasis should be placed on the usefulness, value and relevance of the information contained in annual reports. With increasing exposure to international capital markets, South African companies have been obliged to satisfy the information demands of foreign investors and to provide these investors with more transparent, meaningful, reliable and relevant information in their annual reports. Improvement of the quality, extent 
and informativeness of both mandatory and voluntary disclosures in annual reports may assist the market mechanism to function efficiently and thereby facilitate the effective distribution of capital, assets and even human resources.

\subsection{Purpose of the study}

The purpose of this paper is to compare and evaluate the perceptions of the users and the compilers of annual and interim reports on the importance of voluntary disclosure while taking into account the effect of information on the market price of the shares of the company. Areas of disagreement are identified and proposals made regarding the adding of value to the future development and fundamental reform of voluntary disclosure practices of listed industrial companies in South Africa.

\subsection{Voluntary disclosure}

Users of corporate annual and interim reports require an extensive range of financial and non-financial information, whether mandatory or voluntary, in order to assess the fair value of an investment in shares. Directors of companies need to make decisions in favour of or against the disclosure of certain informative items and are in a position to enhance the effectiveness of the chosen tool of communication, namely the annual report. However, the current system of financial reporting mainly presents historical and factual financial information, neglecting relevant economic, political, environmental, ethical and social issues, because they are regarded to be immeasurable in monetary terms. Gray (1994:27) has noted that accounting should be a social rather than a strictly economic concept and that a broader concept of accountability would recognise a wide range of groups or individuals that have the potential right to more information that is not strictly measurable in monetary terms and is of a voluntary nature. Shareholders, employees, customers and society in general have a right to financial and nonfinancial information. Therefore, by voicing their opinions and putting pressure on the compilers of annual reports to include more qualitative information, users can contribute towards a more valuable form of accountability.

What types of voluntary information should be disclosed? Historically, annual reports were compiler-oriented and not user-oriented. It was left to the compiler of an annual report to decide whether to take a negative approach and to provide only the minimum of information required by statute, or to present the corporation's financial performance in the most favourable way by disclosing more information than the required statutory minimum. The model presented by Verrechia (1983) offers an equilibrium threshold level of disclosure, which is a function of proprietary cost. The threshold level of disclosure is the point above 
which a manager chooses to disclose what he observes and below which he withholds information.

Two types of disclosure appear in annual reports, namely mandatory disclosure and discretionary or voluntary disclosure. Mandatory disclosure refers to those aspects and items of information that are required by statutes, stock exchanges or prescribers of accounting standards. The Companies Act and accounting standards normally prescribe minimum disclosure requirements, but do not prohibit companies from providing additional information. Voluntary disclosure refers to information made available at the discretion of the corporation. The extent of voluntary disclosure is influenced by changes in the attitudes in society, economic factors and behavioural factors such as the particular corporate culture.

\subsection{Voluntary disclosure policy}

A clear and consistent disclosure policy may lead to greater shareholder loyalty and enhance the company's credibility with investors. By developing and improving voluntary disclosure strategies that have a positive impact on the company's standing, as perceived by investors, a company may influence the market price of its shares (Fishman \& Hagerty, 1989). However, reporting excellence is no guarantee that a company's investors will accord it a favourable market rating, particularly if the financial performance of the company is weak. There is therefore a great deal of controversy regarding whether a company's voluntary disclosure policy has an impact on its share price. Fishman and Hagerty $(1989: 643)$ agree that additional disclosure does increase the stability of prices, but contend that the benefits do not justify the costs. Voluntary disclosure items may be classified into historical, current and predictive items, depending on whether they are based on the past, present or envisaged performance of the company.

There are many factors and considerations that could influence a company's overall voluntary disclosure policy. These factors include the extent, frequency and method of disclosure; the company's objectives with disclosure; the size, listing status, culture and complexity of the company; the size, type and culture of the company's shareholders; the cost of disclosure; the favourableness of the news; and the intensity of competition, earnings margins and rate of return. However, as a result of the heterogeneous nature of users, there is no optimum voluntary disclosure policy for a company to adopt. Ideally, compilers and users should jointly draft a conceptual framework that will satisfy the various and often conflicting needs of both groups. Ogan and Ziebart (1991:389) state that it is imperative that the accounting profession should consider the various constituencies of the firm rather than assuming, myopically, that there is a single "general" user of financial statement information. Enterprises, too, should weigh up the adverse risk-sharing effect against 
the beneficial cost-saving effect that disclosure has on shareholders and should balance this comparison with information acquisition costs (Kim 1993:747).

Harrison (1993:74) identifies two types of disclosure policies that companies may adopt, namely a liberal and a restrictive disclosure policy. His arguments in favour of a liberal disclosure policy are similar to those put forward by Atiase, Bamber and Freeman (1988:20), namely that it reduces the volatility of the company's share price and helps to build credibility with the investment community. In addition, a liberal policy of frequent disclosure discourages the market from overreacting to any single announcement of an important event by the company, which in turn decreases the volatility of the company's share price. Arguments against a liberal disclosure policy are that it is costly and requires a great deal of time and effort and may reveal important information to competitors.

\section{Empirical studies on the perceived importance of voluntary disclosure}

Numerous studies have addressed the perceptions of the various parties that have an interest in annual reports on the importance of voluntary disclosure when making an investment decision. Researchers have advanced various reasons why companies should disclose more voluntary information. These reasons include that it reduces the cost of capital, affects the company's share price and affects the company's ability to raise funds in capital markets. A summary of some of these research studies is provided in table 1.

The study by Buzby (1975) consisted of 39 items of financial and nonfinancial information appearing in annual reports, which was then presented to a selected user group of professional financial analysts. In addition, a worksheet that utilised the same items was developed in order to measure the extent of disclosure in the annual reports of 88 small and medium-sized companies. The results revealed that many items of information, which financial analysts believed to be important, were not being adequately disclosed and that there was little correlation between the relative importance of the items and the extent of their disclosure.

The objective of the study undertaken by Benjamin and Stanga (1977) was to compare the perceived information requirements of two groups of users of annual reports, namely commercial bank loan officers and professional financial analysts. The study revealed that bankers, when making term-loan decisions, did not value information to the same extent as did financial analysts when making common stock-investment decisions. This conclusion applied to 51 of the 79 information items in which a significant difference was noted. 
In view of the fact that financial directors are responsible for determining the disclosure policy that the company should adopt after considering the needs of the end users, Firth (1978) examined the importance of individual voluntary disclosure items as rated by finance directors, auditors, financial analysts and bank loan officers. His findings revealed that the rating of importance by finance directors and auditors was similar to that of financial analysts, but significant differences were found between the two groups.

The study by McNally, Eng and Hasseldine (1982) focused on the importance of financial and non-financial information by surveying the attitudes of financial editors and stock exchange members and by relating the preferences of these users to the level of disclosure by companies listed on the New Zealand Stock Exchange. The findings indicated that the level of disclosure was considerably lower than that considered desirable by the external users and that size was a dominant corporate characteristic in identifying the leading companies in respect of voluntary disclosure practices.

In their study, Firer and Meth (1986) investigated the extent to which the non-statutory information requirements of investors were met by the disclosure practices in the annual reports of South African companies. Little positive correlation was found between the investors' information requirements and the disclosure of such information in annual reports.

Courtis (1992) used a metatheory to accumulate findings from 11 perception consensus studies undertaken over a period of 16 years. All the studies based their analysis on means calculated from perception aggregations of lists of information items. The purpose of the investigation was to determine whether consensus of perception existed across diverse studies and between different user and preparer groups. His findings can be summarised as follows:

- Users and preparers perceived approximately $30 \%$ of the common items to be consistent in terms of their importance in respect of information;

- information items that have a future orientation were, as a group, perceived to be more important than items that have a historical or contemporary orientation;

- financial analysts appeared to exercise less variability than other groups in their perception of the importance of specific items;

- $\quad$ sophisticated users perceived items regarding investment and bank-loan decisions to be more important than non-sophisticated users did;

- financial analysts attached more importance to items than the preparers of the information; and

- $\quad$ per item group perceptions appeared to be the same. 
Table 1: Summary of previous studies that investigated the perceptions of users and compilers, indicating the number of disclosure items analysed, type of user group and scale of importance used in the study

\begin{tabular}{|c|c|c|c|c|}
\hline Researcher & $\begin{array}{l}\text { No. of } \\
\text { items }\end{array}$ & Type of user group & $\begin{array}{l}\text { Likert } \\
\text { scale } \\
\text { used }\end{array}$ & $\begin{array}{l}\text { No. of } \\
\text { respon- } \\
\text { dents }\end{array}$ \\
\hline $\begin{array}{l}\text { Buzby (1975) } \\
\text { USA }\end{array}$ & 39 & Financial analysts & $0-4$ & 131 \\
\hline $\begin{array}{l}\text { Benjamin and } \\
\text { Stanga (1977) } \\
\text { USA }\end{array}$ & 79 & $\begin{array}{l}\text { Bank loan officers } \\
\text { and professional } \\
\text { financial analysts }\end{array}$ & $0-4$ & 208 \\
\hline $\begin{array}{l}\text { Firth (1978, } \\
\text { 1979) UK }\end{array}$ & 75 & $\begin{array}{l}\text { Financial directors, } \\
\text { auditors, financial } \\
\text { analysts and bank } \\
\text { loan officers }\end{array}$ & $1-5$ & $\begin{array}{l}\text { Various } \\
\text { samples }\end{array}$ \\
\hline $\begin{array}{l}\text { McNally, Eng } \\
\text { and Hasseldine } \\
\text { (1982) New } \\
\text { Zealand }\end{array}$ & 41 & $\begin{array}{l}\text { Financial editors and } \\
\text { stock exchange } \\
\text { members }\end{array}$ & $1-5$ & 9 \\
\hline $\begin{array}{l}\text { Firer and Meth } \\
\text { (1985) South } \\
\text { Africa }\end{array}$ & 49 & $\begin{array}{l}\text { Members of the } \\
\text { Investment Analysts } \\
\text { Society of Southern } \\
\text { Africa }\end{array}$ & $1-5$ & 137 \\
\hline $\begin{array}{l}\text { Courtis (1992) } \\
\text { Australia }\end{array}$ & 63 & Private shareholders & $1-5$ & 274 \\
\hline $\begin{array}{l}\text { Eccles and } \\
\text { Mavrinac (1995) } \\
\text { USA }\end{array}$ & - & $\begin{array}{l}\text { Corporate managers, } \\
\text { financial analysts and } \\
\text { portfolio managers }\end{array}$ & $1-7$ & - \\
\hline
\end{tabular}

In an effort to determine the key factors for a high-level of corporate disclosure, Eccles and Mavrinac (1995) focused on the disclosure process itself and on the perceptions of constituents. They conducted a survey among corporate managers, financial analysts and portfolio managers to determine their opinions on disclosure regulations and how companies communicated with the capital markets. Their findings revealed that, although the respondents did not support an increase in the regulation of disclosure, there was a need for companies to upgrade the role of the investor-relations personnel; report non-financial information voluntarily; formulate explicit disclosure strategies and policies; and reach out to capital-market customers and solicit their needs, opinions and preferences in order to close the communication gap. 


\section{Empirical study of the perceptions of compilers and users}

Obviously, voluntary disclosure is an extensive field of study and it would have been practically impossible to include all areas of voluntary disclosure in this study of the desirability and importance of voluntary disclosure of information in annual reports. The study was therefore limited to the voluntarily disclosed items that are listed in table 2.

\section{Formulation of the hypothesis}

The data gathered by means of the two questionnaires were used to test the following hypothesis:

Opinions of users and compilers differ with regard to the priceinformative value and importance of voluntarily disclosed items in the annual and interim reports of listed industrial companies in South Africa.

In the final analyses of the perceptions of compilers and users, similarities and differences of significance regarding the price-informative value of various voluntarily disclosed items are highlighted in order to ensure the future utility of financial reporting.

\subsection{Methodology and data-base}

The investigation took the form of a perception survey. The opinions of compilers and users were obtained by means of questionnaires. It was essential to give careful consideration to the development, design and testing of the questionnaires to ensure the reliability, validity and quality of data gathered by means of mail questionnaires. The questionnaires were designed to extract from the internal and external users of the annual and interim reports of the listed industrial companies in South Africa the relative importance of 49 voluntarily disclosed items (refer to table 2 for a list of voluntarily disclosed items) within the context of an evaluation of a company's shares as a potential investment. The items selected were based on the items used by the Bureau of Financial Analysis in 1998 to evaluate the level of voluntary disclosure in annual reports of listed companies to select the top twenty companies that have the highest level of voluntary disclosure. These items are similar to the items used in the research studies of Buzby (1974 and 1975), Firth (1979 and 1984) and Adams and Hossain (1998).

The questionnaires addressed to users and compilers consisted of the following three sections:

Section 1: Biographical information of the users and compilers.

Meditari Accountancy Research Vol. 9 2001: 199-216 
Section 2: General information on how extensively annual reports are used in the decision-making process regarding investments.

Section 3: The ranking accorded by respondents to 49 voluntary disclosure items that are categorised as follows:

3.1 Additional reports and statements in a corporate report.

3.2 Value-added statements.

3.3 Fixed and intangible assets.

3.4 Contents of a table of comparative statistics.

3.5 General voluntarily disclosed items of a qualitative nature.

3.6 Profile and shareholding of directors and top management, distribution of shareholdings and group structure.

3.7 Contents of the directors' report and the chairman's report.

3.8 Interim reports.

In both questionnaires, the compilers and the users were required to rate or rank each disclosure item in terms of a designated scale of perceived importance. The scale was based on the level of importance that they attach to voluntarily disclosed items with regard to price informativeness when making decisions on investments. Similar scales were used by Firth (1978/79); McNally, Eng and Hasseldine (1982); Firer and Meth (1986); and Courtis (1992). A five-point Likert scale was used with a rating of 5 indicating very important, 4 fairly important, 3 moderately important, 2 slightly important and 1 unimportant. On this scale, a score of 4 or 5 indicates that the item is perceived to be essential within the framework of its task. A score of 3 or 2 indicates that the item is perceived to be fairly important, but not essential, while a score of 1 indicates that the item could be disregarded for disclosure purposes.

\subsection{Selection of population groups}

The main objective of publishing a corporate annual report, namely that it should be a communication tool between the management of the company and the owners of the company, formed the point of departure for the identification of the population groups for the study. It resulted in two population groups being selected for the survey, namely:

- $\quad$ Compilers of annual reports, and

- users of annual reports.

The target group selected in respect of the compilers of annual reports consisted of the financial directors or chief accounting officers of all the industrial companies on the JSE Securities Exchange SA listed in the JSE handbook of 1998. It was considered necessary to obtain the personal perceptions and opinions of these compilers, irrespective of the 
policy of the company by which they were employed, concerning the importance of voluntary disclosure in annual reports and its effect on share prices. During June 1998, a total of 357 questionnaires were mailed to the financial directors of the listed companies, of which 135 were returned and 129 utilised in the study. The response rate of $36 \%$ was considered to be adequate.

The second target group, namely the users of annual reports, was a highly diversified group, comprising stockbrokers, share portfolio holders, accounting academics, accounting conference delegates, members of professional accounting bodies and individual investors that are members of the general public. The members of the group were selected on the basis that they were all primary users of annual reports, financially literate and actively engaged in evaluating investments. Users were randomly selected from lists of brokers, lists of clients obtained from brokers and lists of financial analysts. Of the 500 questionnaires mailed to the users of annual reports, $102(20,4 \%)$ were returned and used in the study.

\subsection{Data preparation and processing}

After editing the data for relevance, completeness and accuracy, the data were analysed by means of the SAS system (Statistical Analysis System) of the Bureau of Financial Analysis at the University of Pretoria. An analysis of variance (ANOVA) test, in which the mean scores of two or more groups were compared, was used to determine whether the differences between the perceptions of the two sample groups were statistically significant. Table 2 provides the mean level of importance used to rank the importance of each item. The standard deviation Fvalues, or the degrees of freedom, and probability values indicate whether the differences between the results of the two groups are statistically significant.

\subsection{Descriptive statistics of the biographical profile of the respondents}

The biographical profiles of the respondents were investigated in order to determine their level of financial sophistication. It appeared that the majority of the respondents were highly qualified in the field of accounting. A total of $110(85,3 \%)$ of the compilers and $81(79,4 \%)$ of the users were qualified chartered accountants or held a master's degree or a doctorate in Accounting.

The second biographical question dealt with the number of years of experience that the respondent had had in the field of investment analysis (users) or finance (compilers). The fact that $96(70,0 \%)$ compilers and $62(60,8 \%)$ users had had more than ten years of experience, indicates that the respondents were very knowledgeable and 
financially sophisticated and could be considered to be experts in their fields. To determine the reliability of the data, it was necessary to obtain some idea of the compiler's position in the company. This information was elicited by means of a third question in the questionnaire that was addressed to compilers. The aim of the question was to establish whether the respondent was actively engaged in the preparation of annual report and whether he or she was familiar with voluntary disclosure. The managerial positions held by the compiler respondents were as follows: $2,3 \%$ were managing directors, $48,1 \%$ held the position of financial director, $13,2 \%$ operated as chief accountants, $14,7 \%$ were financial controllers and $7,0 \%$ were company secretaries. Other positions held were that of group financial manager; financial manager; project accountant; senior manager of group finance; group tax advisor; planning and public relations executive; technical accounting manager; general manager of finance; corporate accountant; and commercial director. The fact that $48,1 \%$ of the respondents held the position of financial director of a company, implies that they were financially sophisticated.

\title{
5 Results of the empirical study
}

The perceptions of the compilers and the users were analysed to determine whether the null hypothesis could be rejected, that is to identify statements that refute that "there is no difference between the perceptions of compilers and users of the importance of disclosing certain voluntary items". In the analysis of the results, the introductory instruction, which was addressed to the compilers and the users for the completion of the questionnaires, had to be borne in mind, namely:

\begin{abstract}
"Rank the level of importance of the following voluntary information disclosure items appearing in any listed company's annual and interim report in terms of what you personally consider will have an effect on the market price of the shares of the company."
\end{abstract}

To substantiate the conclusions and findings of this investigation into the consensus of the perception of compilers and users, an item by item comparison of the means, standard deviations and ranking of the importance of perceptions were used as an additional analytical statistic. The mean for each item represents overall measures of the degree of importance that respondents assigned to the items within the context of price-informative value. A high mean score is associated with a high degree of importance. The mean was thereafter used to facilitate numerical rankings of the voluntarily disclosed items for each respondent group. An analysis and an interpretation of the consensus of perceptions were obtained by cross-tabulation of the data obtained from the two questionnaires. The results of the examination are summarised in table 2. 
Table 2: Summary of rankings by users and compilers of the importance of voluntarily disclosed items

\begin{tabular}{|c|c|c|c|c|c|c|c|}
\hline \multirow{3}{*}{$\begin{array}{l}\text { Voluntarily disclosed } \\
\text { item }\end{array}$} & \multicolumn{6}{|c|}{ Respondents } & \multirow[b]{3}{*}{$\begin{array}{c}\text { Level o } \\
\text { signifi- } \\
\text { cance }\end{array}$} \\
\hline & \multicolumn{3}{|c|}{ Users } & \multicolumn{3}{|c|}{ Compilers } & \\
\hline & Mean & Rank & $\begin{array}{l}\text { Standard } \\
\text { deviation }\end{array}$ & Mean & Rank & $\begin{array}{l}\text { Standard } \\
\text { deviation }\end{array}$ & \\
\hline $\begin{array}{l}1 \text { Reasons for } \\
\text { changes in results } \\
\text { addressed by } \\
\text { director or chairman }\end{array}$ & 4.759 & 1 & 0.512 & 4.770 & 2 & 0.443 & NSD \\
\hline 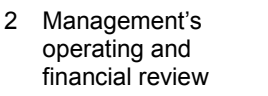 & 4.747 & 2 & 0.650 & 4.779 & 1 & 0.438 & NSD \\
\hline $\begin{array}{l}\text { Turnover or revenue } \\
\text { disclosed in the } \\
\text { interim report }\end{array}$ & 4.709 & 3 & 0.484 & 4.655 & 4.5 & 0.563 & NSD \\
\hline $\begin{array}{l}4 \text { Turnover or revenue } \\
\text { figure disclosed in } \\
\text { the table of } \\
\text { comparative } \\
\text { statistics }\end{array}$ & 4.658 & 4 & 0.677 & 4.655 & 4.5 & 0.594 & NSD \\
\hline $\begin{array}{l}5 \text { Future dividend and } \\
\text { profit expectations } \\
\text { in the interim report }\end{array}$ & 4.557 & 5 & 0.655 & 4.451 & 10 & 0.694 & NSD \\
\hline $\begin{array}{l}6 \text { Detailed discussion } \\
\text { of activities in the } \\
\text { directors' or the } \\
\text { chairman's report }\end{array}$ & 4.544 & 6 & 0.676 & 4.469 & 9 & 0.599 & NSD \\
\hline $\begin{array}{l}\text { Cost of sales } \\
\text { disclosed in the } \\
\text { annual report }\end{array}$ & 4.538 & 7 & 0.658 & 4.053 & 22 & 0.833 & SD \\
\hline 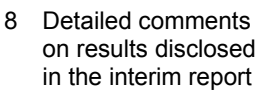 & 4.494 & 8 & 0.732 & 4.602 & 6 & 0.543 & NSD \\
\hline $\begin{array}{l}\text { Net asset value } \\
\text { disclosed in the } \\
\text { table of comparative } \\
\text { statistics }\end{array}$ & 4.405 & 9.5 & 0.913 & 4.513 & 8 & 0.628 & NSD \\
\hline $\begin{array}{l}10 \text { Profitability ratio } \\
\text { disclosed in the } \\
\text { table of comparative } \\
\text { statistics }\end{array}$ & 4.405 & 9.5 & 0.885 & 4.708 & 3 & 0.494 & SD \\
\hline $\begin{array}{l}11 \text { Individual } \\
\text { shareholdings of } \\
\text { directors and top } \\
\text { management }\end{array}$ & 4.405 & 9.5 & 0.777 & 4.071 & 21 & 0.741 & SD \\
\hline $\begin{array}{l}12 \text { Long-term dividend } \\
\text { policy }\end{array}$ & 4.385 & 12 & 0.793 & 4.089 & 19 & 0.651 & SD \\
\hline $\begin{array}{l}13 \text { Corporate goals or } \\
\text { mission statement }\end{array}$ & 4.367 & 13 & 0.754 & 4.389 & 12 & 0.687 & NSD \\
\hline $\begin{array}{l}\text { Cash-flow } \\
\text { statement } \\
\text { disclosed in the } \\
\text { interim report }\end{array}$ & 4.329 & 14 & 0.796 & 4.186 & 17 & 0.902 & NSD \\
\hline
\end{tabular}


Table 2 (continued)

\begin{tabular}{|c|c|c|c|c|c|c|c|c|}
\hline \multirow{3}{*}{\multicolumn{2}{|c|}{$\begin{array}{l}\text { Voluntarily disclosed } \\
\text { item }\end{array}$}} & \multicolumn{6}{|c|}{ Respondents } & \multirow[b]{3}{*}{$\begin{array}{l}\text { Level of } \\
\text { signifi- } \\
\text { cance }\end{array}$} \\
\hline & & \multicolumn{3}{|c|}{ Users } & \multicolumn{3}{|c|}{ Compilers } & \\
\hline & & Mean & Rank & $\begin{array}{l}\text { Standard } \\
\text { deviation }\end{array}$ & Mean & Rank & $\begin{array}{l}\text { Standard } \\
\text { deviation }\end{array}$ & \\
\hline 15 & $\begin{array}{l}\text { Liquidity and } \\
\text { solvability ratios } \\
\text { disclosed in the } \\
\text { table of statistics }\end{array}$ & 4.304 & 15 & 0.992 & 4.602 & 6 & 0.606 & SD \\
\hline 16 & $\begin{array}{l}\text { Differentiation } \\
\text { between interest- } \\
\text { bearing and non- } \\
\text { interest-bearing } \\
\text { debt }\end{array}$ & 4.260 & 16 & 0.785 & 4.223 & 16 & 0.732 & NSD \\
\hline 17 & $\begin{array}{l}\text { Group structure } \\
\text { presented } \\
\text { diagrammatically } \\
\text { with detailed } \\
\text { information }\end{array}$ & 4.241 & 17 & 0.851 & 4.080 & 20 & 0.769 & NSD \\
\hline 18 & $\begin{array}{l}\text { Number of shares } \\
\text { issued disclosed } \\
\text { in table of } \\
\text { comparative } \\
\text { statistics }\end{array}$ & 4.228 & 18 & 1.012 & 4.451 & 10 & 0.681 & NSD \\
\hline 19 & $\begin{array}{l}\text { Comparison of } \\
\text { company's share } \\
\text { price with the } \\
\text { industry index }\end{array}$ & 4.190 & 19 & 0.878 & 4.053 & 22 & 0.822 & NSD \\
\hline 20 & $\begin{array}{l}\text { Productivity ratios } \\
\text { disclosed in the } \\
\text { table of } \\
\text { comparative } \\
\text { statistics }\end{array}$ & 4.177 & 20.5 & 0.874 & 4.372 & 13 & 0.697 & NSD \\
\hline 21 & $\begin{array}{l}\text { Distribution of } \\
\text { total shareholding } \\
\text { according to size } \\
\text { and type }\end{array}$ & 4.177 & 20.5 & 0.730 & 3.956 & 25 & 0.686 & SD \\
\hline 22 & $\begin{array}{l}\text { Audited interim } \\
\text { report }\end{array}$ & 4.076 & 22 & 1.010 & 3.230 & 45 & 0.926 & SD \\
\hline 23 & $\begin{array}{l}\text { Statement that } \\
\text { report complies } \\
\text { with international } \\
\text { accounting } \\
\text { standards }\end{array}$ & 4.026 & 23 & 0.993 & 3.735 & 34 & 0.824 & SD \\
\hline 24 & $\begin{array}{l}\text { Segmental } \\
\text { information } \\
\text { disclosed in the } \\
\text { interim report }\end{array}$ & 4.025 & 24 & 0.800 & 3.920 & 27 & 0.781 & NSD \\
\hline 25 & $\begin{array}{l}\text { List of activities of } \\
\text { all subsidiaries } \\
\text { disclosed or } \\
\text { available to the } \\
\text { public }\end{array}$ & 4.013 & 25 & 0.875 & 4.027 & 24 & 0.700 & NSD \\
\hline 26 & $\begin{array}{l}\text { Depreciation of } \\
\text { intangible assets }\end{array}$ & 4.013 & 26 & 0.954 & 3.813 & 30 & 0.833 & NSD \\
\hline 27 & $\begin{array}{l}\text { Definitions of } \\
\text { financial ratios }\end{array}$ & 4.000 & 27.5 & 1.062 & 4.363 & 14 & 0.768 & SD \\
\hline
\end{tabular}


Table 2 (continued)

\begin{tabular}{|c|c|c|c|c|c|c|c|c|}
\hline \multirow{3}{*}{\multicolumn{2}{|c|}{$\begin{array}{l}\text { Voluntarily disclosed } \\
\text { item }\end{array}$}} & \multicolumn{6}{|c|}{ Respondents } & \multirow[b]{3}{*}{$\begin{array}{c}\text { Level of } \\
\text { signifi- } \\
\text { cance }\end{array}$} \\
\hline & & \multicolumn{3}{|c|}{ Users } & \multicolumn{3}{|c|}{ Compilers } & \\
\hline & & Mean & Rank & $\begin{array}{l}\text { Standard } \\
\text { deviation }\end{array}$ & Mean & Rank & $\begin{array}{l}\text { Standard } \\
\text { deviation }\end{array}$ & \\
\hline 28 & $\begin{array}{l}\text { Biographical } \\
\text { profile of directors } \\
\text { and top } \\
\text { management }\end{array}$ & 4.000 & 27.5 & 0.816 & 3.956 & 25 & 0.724 & NSD \\
\hline 29 & $\begin{array}{l}\text { Volume and value } \\
\text { of shares traded, } \\
\text { and lowest, } \\
\text { highest and year- } \\
\text { end prices }\end{array}$ & 3.975 & 29 & 1.143 & 4.159 & 18 & 0.808 & NSD \\
\hline 30 & $\begin{array}{l}\text { Insurance or } \\
\text { replacement value } \\
\text { of assets other } \\
\text { than fixed } \\
\text { property }\end{array}$ & 3.937 & 30 & 0.896 & 3.473 & 40 & 0.782 & SD \\
\hline 31 & $\begin{array}{l}\text { Movement of fixed } \\
\text { assets shown in } \\
\text { the cash-flow } \\
\text { statement }\end{array}$ & 3.911 & 31 & 1.064 & 3.866 & 28 & 0.729 & NSD \\
\hline 32 & $\begin{array}{l}\text { Highlights } \\
\text { disclosed } \\
\text { separately in the } \\
\text { annual report }\end{array}$ & 3.910 & 32 & 0.942 & 4.274 & 15 & 0.644 & SD \\
\hline 33 & $\begin{array}{l}\text { Research and } \\
\text { development cost }\end{array}$ & 3.792 & 33 & 0.879 & 3.646 & 36 & 0.778 & NSD \\
\hline 34 & $\begin{array}{l}\text { Value-added } \\
\text { statements } \\
\text { presented as a } \\
\text { statement }\end{array}$ & 3.772 & 34 & 1.074 & 3.777 & 32 & 0.908 & NSD \\
\hline 35 & $\begin{array}{l}\text { Tax-reconciliation } \\
\text { statement }\end{array}$ & 3.709 & 35 & 0.989 & 3.841 & 29 & 0.786 & NSD \\
\hline 36 & $\begin{array}{l}\text { Research and } \\
\text { development } \\
\text { projects discussed } \\
\text { in detail }\end{array}$ & 3.688 & 36 & 0.892 & 3.717 & 35 & 0.807 & NSD \\
\hline 37 & $\begin{array}{l}\text { Value-added } \\
\text { statements } \\
\text { presented for two } \\
\text { years }\end{array}$ & 3.620 & 37 & 1.054 & 3.504 & 39 & 0.992 & NSD \\
\hline 38 & $\begin{array}{l}\text { Promotion of } \\
\text { activities }\end{array}$ & 3.526 & 38 & 0.817 & 3.607 & 38 & 0.764 & NSD \\
\hline 39 & $\begin{array}{l}\text { Inflation-adjusted } \\
\text { financial } \\
\text { statements }\end{array}$ & 3.380 & 39.5 & 0.978 & 3.009 & 49 & 0.807 & SD \\
\hline 40 & $\begin{array}{l}\text { Number of } \\
\text { employees }\end{array}$ & 3.380 & 39.5 & 0.951 & 3.761 & 33 & 0.837 & SD \\
\hline 41 & $\begin{array}{l}\text { Value-added } \\
\text { statement } \\
\text { presented for one } \\
\text { year }\end{array}$ & 3.367 & 40 & 0.963 & 3.402 & 41 & 0.972 & NSD \\
\hline 42 & $\begin{array}{l}\text { Environmental } \\
\text { reporting }\end{array}$ & 3.367 & 41.5 & 0.989 & 3.053 & 48 & 0.800 & SD \\
\hline
\end{tabular}


Table 2 (continued)

\begin{tabular}{|c|c|c|c|c|c|c|c|c|}
\hline \multirow{3}{*}{\multicolumn{2}{|c|}{$\begin{array}{l}\text { Voluntarily disclosed } \\
\text { item }\end{array}$}} & \multicolumn{6}{|c|}{ Respondents } & \multirow[b]{3}{*}{$\begin{array}{c}\text { Level of } \\
\text { signifi- } \\
\text { cance }\end{array}$} \\
\hline & & \multicolumn{3}{|c|}{ Users } & \multicolumn{3}{|c|}{ Compilers } & \\
\hline & & Mean & Rank & $\begin{array}{l}\text { Standard } \\
\text { deviation }\end{array}$ & Mean & Rank & $\begin{array}{l}\text { Standard } \\
\text { deviation }\end{array}$ & \\
\hline 43 & $\begin{array}{l}\text { Employee/social } \\
\text { report }\end{array}$ & 3.291 & 43 & 0.963 & 3.327 & 42 & 0.761 & NSD \\
\hline 44 & $\begin{array}{l}\text { Results presented } \\
\text { graphically }\end{array}$ & 3.244 & 44 & 0.856 & 3.779 & 31 & 0.704 & SD \\
\hline 45 & $\begin{array}{l}\text { Value-added } \\
\text { statement } \\
\text { presented as a pie } \\
\text { chart }\end{array}$ & 3.241 & 45 & 0.964 & 3.292 & 44 & 0.903 & NSD \\
\hline 46 & $\begin{array}{l}\text { List of fixed } \\
\text { property available } \\
\text { for inspection by } \\
\text { the public }\end{array}$ & 3.215 & 46 & 1.009 & 31.79 & 46 & 0.841 & NSD \\
\hline 47 & $\begin{array}{l}\text { Shareholders' } \\
\text { diary }\end{array}$ & 3.192 & 47 & 1.082 & 3.628 & 37 & 0.878 & SD \\
\hline 48 & $\begin{array}{l}\text { Statement of } \\
\text { money exchanges } \\
\text { with government }\end{array}$ & 2.987 & 48 & 1.080 & 3.124 & 47 & 0.857 & NSD \\
\hline 49 & $\begin{array}{l}\text { Illustrations and } \\
\text { colour }\end{array}$ & 2.897 & 49 & 0.862 & 3.327 & 42 & 0.796 & SD \\
\hline
\end{tabular}

Rank = Based on the mean score of each item

SD = Statistically significant at the 0.01 level

NSD = Not statistically significant at the 0.01 level

Number of significant differences between group means $=17$ (out of 49).

In general, the responses to the questionnaires indicated that both groups attached a high level of importance to the majority (32 out of 49) of the voluntarily disclosed items and that compilers and users were in substantial agreement regarding their weightings. According to table 2, the following four voluntarily disclosed items were ranked as being the most important to compilers and users, and there was no significant difference between their perceptions:

- Reasons for changes in results addressed by the managing director or chairman;

- management's operating and financial review;

- turnover or revenue figure disclosed in the interim report; and

- turnover or revenue figure disclosed in the table of comparative statistics.

Expectational items, such as items 2, 5, 12 and 13, were ranked highly by both the users and the compilers. These results are in line with Courtis' (1992) finding that expectational information was perceived to be more important in respect of investment decisions than historical and current information. His investigation covered 11 studies undertaken 
over a period of 16 years in six countries and across six user-preparer groups.

Considered on an item by item basis, 17 significant perceptual differences were found among the 49 items that were analysed. Examples of these items are: cost of sales disclosed in the annual report; ratios disclosed in the table of comparative statistics; individual shareholdings of directors and top management; audited interim reports; and compliance with international accounting standards. Any significant difference between the opinions of compilers and of users may amongst others things be attributed to the fact that compilers are hesitant to disclose valuable information to competitors and that compilers bear in mind the cost of disclosing additional information such as inflationadjusted financial statements. This view is supported by Gray, Radebaugh and Roberts (1990:606) who found that, on average, financial executives tend to perceive most voluntary disclosure items in terms of their net cost. Consequently, disclosure is dependent on the outcome of an assessment of the economic consequences of the proposed disclosure item. Gray et al (1990) also found that there is general agreement among financial executives that the most important cost factor is the indirect cost of competitive disadvantage resulting from the disclosure of information such as future-orientated information and defined-segment information.

\section{Conclusion}

This study investigated the informational importance of voluntary disclosure relevant to a company's share price as perceived by the compilers and the users of annual reports. No significant differences were found between the perception of the compilers and of the users in the case of 32 of the 49 voluntarily disclosed items.

To extend reporting regulations will not close the "communication gap". Future setters of accounting standards should be wary of falling into the trap of changing voluntary items into requirements. Such a situation would contribute to disclosure overload, without necessarily adding value to annual reports. The solution should rather be sought in focusing on an improvement of the corporate disclosure process.

\section{$7 \quad$ Recommendations for future research}

Even disclosures that are made voluntarily should be reliable and consistent and should improve the quality of corporate communication. Furthermore, the interest of the users of corporate annual reports should take precedence over the interests of the compilers. Compilers and auditors should identify what is perceived to be useful decision-making information in terms of user needs and should respond by improving the 
non-financial information content of the annual report and by formulating an effective disclosure policy.

There is, however, a fine balance between the provision of useful information and information overload. The solution to the problem of information overload proposed by Wallman (1997:110) is a usercustomised system in which the users determine what information they wish to access from a comprehensive disaggregated database to enable them to prepare their own customised financial statements from real-time information. Such a solution would, firstly, bring about enormous cost savings for corporations, because the publication of an annual report is a costly annual exercise. Secondly, such a real-time access data system would aid the investors' decision making, because it would decrease uncertainty. On the other hand, such a system would provide competitors with valuable information. Electronic data will certainly be the primary source of information in the future and annual reports should already be geared to this method of disseminating information.

Further research could expand on voluntary disclosure by covering the following topics:

- A code of ethical accounting practices;

- operating and financial review statements or management's discussion and analysis reports, for example as required by the Securities and Exchange Commission in the USA and the Ontario Securities Commission in Canada;

- $\quad$ productivity accounting and productivity statements;

- $\quad$ incentive schemes used to reward directors and management;

- $\quad$ adherence to international accounting standards to enhance the global financial reporting model;

- environmental awareness and conservation;

- $\quad$ price-sensitive information;

- $\quad$ reporting on intangible assets such as intellectual capital; and

- $\quad$ information on websites and e-commerce.

Compilers and users should be encouraged to communicate in order to attain a higher degree of consensus on the extent and importance of voluntary disclosure. Until such time as they reach complete consensus, the information content of annual reports will not totally satisfy the needs of all constituents. It will therefore remain an imperfect mechanism in the communication process.

To avoid financial disclosure overload in future, it may ultimately be necessary to publish separate, supplementary or summarised reports that serve the different needs of the various stakeholders. This problem may be solved by the use of publicly accessible databases such as the Securities and Exchange Commission's electronic data gathering and retrieval system and Compustat. These systems, which are aiding the 
globalisation of financial markets, should also contribute towards the achievement of greater conformity in respect of both mandatory and voluntary disclosure items.

\section{Bibliography}

Adams, M. and Hossain, M. 1998. Managerial discretion and voluntary disclosure: Empirical evidence from the New Zealand life insurance industry, Journal of Accounting and Public Policy, Vol. 17, No. 3, pp.245281.

Atiase, R.K., Bamber, L.S. and Freeman, R.N. 1988. Accounting disclosures based on company size: regulations and capital markets evidence, Accounting Horizons, Vol. 2, No. 1, pp.18-26.

Benjamin, J.J. and Stanga, K.G. 1977. Differences in disclosure needs of major users of financial statements, Accounting and Business Research, No. 27, pp.187-192.

Buzby, S.L. 1974. Selected items of information and their disclosure in annual reports, The Accounting Review, Vol. 49, No. 3, pp.423-435.

Buzby, S,L. 1975. Company size, listed versus unlisted stocks, and the extent of financial disclosure, Journal of Accounting Research, Vol. 13, No. 1, pp.16-37.

Courtis, J. K. 1992. The reliability of perception-based annual report disclosure studies, Accounting and Business Research, Vol. 23, No. 89, pp.31-43.

Eccles, R.G. and Mavrinac, S.C. 1995. Improving the corporate disclosure process, Sloan Management Review, Vol. 36, No. 4, pp.1125.

Firer, C and Meth, G. 1986. Investor information requirements and disclosure in annual reports, The Investment Analysts Journal, No. 27, Part 1, pp.11-17.

Firth, M. 1978. A study of the consensus of the perceived importance of disclosure of individual items in corporate annual reports, The International Journal of Accounting Education and Research, Vol. 14, Part 1, pp.57-70.

Firth, M. 1979. The impact of size, stock market listing and auditors on voluntary disclosure in corporate annual reports, Accounting and Business Research, Vol. 9, No. 36, pp.273-280. 
Firth, M. 1984. The extent of voluntary disclosure in corporate annual reports and its association with security risk measures, Applied Economics, Vol. 16, pp.269-277.

Fishman, M.J. and Hagerty, K.M. 1989. Disclosure decisions by firms and the competition for price efficiency, Journal of Finance, Vol. XLIV, No. 3, pp.633-646.

Gray, S.J., Radebaugh, L.H and Roberts, C.B. 1990. International perceptions of cost constraints on voluntary information disclosures: a comparative study of UK and US multinationals, Journal of International Business Studies, Vol. 21, No. 4, pp.597-621.

Harrison, G.W. 1993. The disclosure dilemma, Discount Merchandiser, Vol. 33, No. 7, pp.73-75.

Kim, O. 1993. Disagreements among shareholders over a firm's disclosure policy, Journal of Finance, Vol. 48, No. 2, pp.747-760.

McNally, G.M., Eng, L.H. and Hasseldine, C.R. Winter 1982. Corporate financial reporting in New Zealand: An analysis of user preferences, corporate characteristics and disclosure practices for discretionary information, Accounting and Business Research, Vol. 49, pp.11-20.

Ogan, P. and Ziebart, D.A. 1991. Corporate reporting and the accounting profession: an interpretive paradigm, Journal of Accounting, Auditing and Finance, Vol. 6, No. 3, pp.387-406.

Verrecchia, R.E. 1983. Discretionary disclosure, Journal of Accounting and Economics, Vol. 5, pp.179-194.

Wallman, S.M.H. 1997. The future of accounting and financial reporting, Part IV: "Access" accounting, Accounting Horizons, Vol. 11, No.2, pp.103-116. 